\title{
Just a Game: the Dangers of Quantifying Medical Student Professionalism
}

\author{
Roshini Pinto-Powell, MD ${ }^{1,2,3}$ and Timothy Lahey, MD, MMSc $c^{4,5}$ \\ 'Department of Medicine, Geisel School of Medicine at Dartmouth, Hanover, NH, USA; ${ }^{2}$ Dartmouth-Hitchcock Medical Center, Lebanon, NH, USA; \\ ${ }^{3}$ Department of Medical Education, Geisel School of Medicine at Dartmouth, Hanover, NH, USA; ${ }^{4}$ Larner College of Medicine, University of \\ Vermont, Burlington, VT, USA; ${ }^{5}$ The University of Vermont Medical Center, Burlington, VT, USA.
}

A medical student on her internal medicine clerkship says her numerical medical professionalism grade was "just a game." Building on this anecdote, we suggest there is good reason to believe that numerical summative assessments of medical student professionalism can, paradoxically, undermine medical student professionalism by sapping internal motivation and converting conversations about core professional values into just another hurdle to residency. We suggest better ways of supporting medical student professional development, including a portfolio comprised of written personal reflection and periodic $360^{\circ}$ formative assessment in the context of longitudinal faculty coaching.

KEY WORDS: professionalism; education; medical; disincentives.

J Gen Intern Med 34(8):1641-4

DOI: $10.1007 / \mathrm{s} 11606-019-05063-\mathrm{x}$

() Society of General Internal Medicine 2019

$\mathrm{T}$ he third-year medical student felt pulled in opposite directions.

Her patient needed her. "Can’t you just stay for a few more minutes?" said the frail 85 -year-old woman. A tremulous hand reached out from under the bedcovers.

It was also time for rounds. The medicine resident leaned in from the doorway and gestured for the student to join.

What followed exemplifies how the numerical assessment of student professionalism can, paradoxically, undermine student professionalism.

The student stayed with her patient. She held the old woman's hand, and listened, and tried to allay her fears. Then, heart racing, the student hustled back to rounds.

When she rejoined the team, the student was reprimanded for not being punctual. The student took a deep breath and defended her choice. She asked if being punctual for rounds really was more important than comforting a fearful patient.

Received August 21, 2018

Revised January 16, 2019

Accepted April 11, 2019

Published online May 30, 2019
More conversations followed. Ultimately, while the student did well on most end-of-rotation metrics, her numerical professionalism grade suffered. "The student was late for teaching rounds," went the written evaluation. She "appears refractory to feedback. She needs to acquire a better understanding of her role on a complex and busy medical team."

The decreased numerical professionalism grade, and the interactions around it, had long-lasting effects on our student. Two years later, just before graduating, the student told us that being downgraded on professionalism points affected her deeply. She realized, she said, "it was all just a game." Rather than a substantive conversation about proper comportment on the wards, or the balancing of ethical priorities, she said, she felt she had had to choose between exhibiting moral courage versus receiving a desirable numerical score from her evaluators. How we graded her professionalism, she felt, was a threat to her actual professionalism.

In 2002, a combined North American and European Internal Medicine Boards project published a Physicians Charter on medical professionalism requirements for the new millennium which included three fundamental principles: primacy of patient welfare, patient autonomy, and social justice. The charter also described ten professional responsibilities: commitment to competence, honesty, confidentiality, managing relationships, quality of care, access to care, just distribution of resources, scientific knowledge, managing conflicts, and professional responsibilities. ${ }^{1}$

We have since made progress toward building these ideals into the ways our medical students learn, including their assessment. Professionalism curricula have proliferated, and most medical schools now incorporate a professionalism statement in the medical student performance evaluation used in residency application process. ${ }^{2}$ Many institutions, like ours, grade professionalism using a numerical point system. ${ }^{3}$

Despite the paucity of published literature about the practice of summative numerical grades of medical student professionalism, a discussion thread on the Clerkship Directors of Inpatient Medicine listserv in June 2018 confirms that other institutions also use a numerical system to grade professionalism. Some institutions award a full 10 points to students at the start of a clinical clerkship and subtract points with each perceived infraction. Points may be subtracted for unexcused absences, tardiness to a session, or not completing an assignment on 
time. Lose a certain number of points and at some institutions a student is automatically unable to receive an Honors grade.

We commend institutions for making professionalism an important part of medical education, and encourage investments in faculty development aimed at ensuring we mentor medical students effectively around their professionalism. ${ }^{4}$ Including the assessment of medical professionalism is a potent way to signal that this material is at least as important as the many other topics on which students are vigorously assessed.

Numerical, summative approaches to the assessment of student medical professionalism, by contrast, have real risks and are susceptible to bias.

Numerical professionalism grades convert opportunities for students to join a culture of personal reflection and discussion of professional formation into just another moment to look good on paper. Rather than focus on respectful adult conversation about which values are important, and how to enact them effectively amid the usual strains of medical practice, numerical grades ask faculty members to distill an irreducibly complex concept, professionalism, into a simple numerical grade. What does a student learn about her diligence, respectful treatment of patients, honesty, and moral courage, for instance, from being told her professionalism rates a 3 or a 6 or a 9 on a 9-point Likert scale of professionalism? We argue she learns little about professionalism other than that she should have gamed the system in order to get a good residency slot. $^{5}$

Summative numerical professionalism grades are also susceptible to bias. We question whether even the most dedicated and involved faculty member is truly qualified to offer a definitive, summative assessment of the full scope of a student's professional development. Might we award favorable grades to students who resemble us? Or who flatter us? At the most, faculty evaluators should admit their perspective on the $24 / 7$ reality of student professionalism is far from exhaustive. It would be hubris for even the most engaged faculty mentor to make an authoritative, summative assessment of the values and professionalism of a student they have often only known for hours.

"One of the things we've been doing in the American school system is making it more and more controlling rather than supportive," educational psychologist Edward Deci said, ${ }^{6}$ summarizing decades of research linking controlling teaching approaches to decreased learner engagement in learning. Most pertinently, external incentives like grades and money can undermine adult learner engagement with complex tasks ${ }^{7}$ and reduce adult workers' sense of connection to workplace values. ${ }^{8}$ Others have suggested Deci's work is relevant to medical education, ${ }^{9}$ and we view medical professionalism as particularly vulnerable to the de-motivating effects of external incentives. Medical professionalism is archetypally complex and irreducibly value-centric and must be nurtured under the increasingly intense external incentives faced by our learners, from grades to board scores to the salary they use to pay off debt and acquire the markers of prestige.

Numerical, summative, and formidably impactful incentivization of short-term, chance-influenced, biassusceptible impressions of student professionalism risk undermining student engagement in professionalism itself. We believe that turning professionalism into just another metric for students to groom could well contribute to student burnout $^{10}$ and waning idealism through medical school. ${ }^{11-15}$

We are not arguing against the assessment of professionalism. Far from it! The assessment of professionalism should evaluate multiple parameters and be formative, rather than summative. ${ }^{16}$ We encourage faculty mentors to discuss professionalism - and challenges to it - at multiple time points throughout the preclinical and clinical curriculum.

Irby and Hamstra describe three professionalism frameworks in medical education: (1) virtue-based, which encompasses the development of moral character and reasoning plus caring and compassion; (2) behavior-based, which emphasizes milestones, competencies, and measurements of observed behavior; and (3) professional identity formation, which focuses on identity development and socialization into a community of practice. Serial discussions between students and their faculty mentors about how this framework of core professional values links to the work they are doing at that stage of training would be immensely valuable to students and far more helpful to their professionalism than an oversimplified, summative professionalism score. We should meet students where they are, and stand by them as they evolve as learners and human beings. ${ }^{17}$

The optimum way to achieve these goals is still being sought by institutions across the country. ${ }^{18}$ We should give input with modesty, knowing our perspective is limited and that we as faculty are far from perfect. ${ }^{19}$ We should talk about moral character, and values, explicitly, as well as behavior. In particular, we appreciate the conversational model outlined by Gracey et al. in which the learner's current stage of professional development is "diagnosed" and then linked to the current clinical experiences with longitudinal feedback. ${ }^{20}$ Formative feedback for students should come from all relevant stakeholders, from physician faculty to nurses to other professionals, from patients, ward clerks, and medical school administrative staff. ${ }^{21}$ We appreciate efforts to develop situational tests that gauge students' ability to enact their values in challenging situations, ${ }^{22}$ with the caveat that a summative score on such an instrument would be less useful to the student's professional development than the feedback received from successes and failures on particular items. We heartily support the inclusion of medical humanities in discussions about professional development, ${ }^{23-25}$ including narrative writing and the use of professionalism portfolios. ${ }^{26} \mathrm{We}$ should avoid, steadfastly, the temptation to debase these nuanced, humble, evolving assessments by converting them into oversimplified numerical summative scores that emphasize hierarchy and 
gaming the residency application system over true reflection about the core values of medicine.

We are also excited to see whether coaching models of medical education support medical student professionalism as effectively as the development of technical skills. ${ }^{27-29}$ To complement curricular efforts that focus on professionalism, we strongly support the longitudinal advising systems that identify student professionalism lapses and provide nonpunitive support for remediation. ${ }^{30}$

Ultimately, the decision to graduate a student from a course or clerkship or from medical school itself is a summative professionalism assessment. Beyond those binary judgments, and a rich portfolio of formative personal reflection and $360^{\circ}$ feedback collected across the curriculum, we do not see the added value of an objective-seeming but ultimately oversimplified and potentially biased summative numerical grade of professionalism.

The medical student (now resident) whose story began this article said recently that she remains open to thoughtful feedback during the rest of her training at the same time she is developing her own internal criteria for professionalism. We are proud she is still attentive to this critical aspect of her development as a clinician, and hope more and more institutions support their students' efforts in self-directed professional formation. The time is long past to find better and more nuanced ways to assess professionalism in students than the current numerical system pervasive in medical education today. We must model the behaviors and attitudes we expect in our students and be willing to listen to the feedback we are receiving. Only then can we move forward, designing evaluative measures that will create and support the future we envision.

Corresponding Author: Roshini Pinto-Powell, MD; Department of Medical Education Geisel School of Medicine at Dartmouth, Hanover, NH, USA (e-mail: Roshini.Pinto-Powell@dartmouth.edu).

\section{Compliance with Ethical Standards:}

Conflict of Interest: The authors declare that they do not have a conflict of interest.

\section{REFERENCES}

1. Medicine AFABoI, Medicine A-AFACoP-ASoI. European Federation of Internal M. Medical professionalism in the new millennium: a physician charter. Ann Intern Med. 2002;136(3):243-6.

2. Hook L, Salami AC, Diaz T, Friend KE, Fathalizadeh A, Joshi ART. The Revised 2017 MSPE: Better, But Not "Outstanding". J Surg Educ. 2018;75(6):e107-e11. https://doi.org/10.1016/j.jsurg.2018.06.014

3. Frohna A, Stern D. The nature of qualitative comments in evaluating professionalism. Med Educ. 2005;39(8):763-8. https://doi.org/10.1111/ j.1365-2929.2005.02234.x

4. Shrank WH, Reed VA, Jernstedt GC. Fostering professionalism in medical education: a call for improved assessment and meaningful incentives. J Gen Intern Med. 2004;19(8):887-92. https://doi.org/10. $1111 /$ j.1525-1497.2004.30635.x
5. Birden HH, Usherwood T. "They liked it if you said you cried": how medical students perceive the teaching of professionalism. Med J Aust. 2013;199(6):406-9.

6. Doucleff M. A Lost Secret: How To Get Kids To Pay Attention. National Public Radio; 2018.

7. Deci EL, Koestner R, Ryan RM. A meta-analytic review of experiments examining the effects of extrinsic rewards on intrinsic motivation. Psychol Bull. 1999;125(6):627-68. discussion 92-700.

8. Roche M, Haar JM. A metamodel approach towards self-determination theory: a study of New Zealand managers' organisational citizenship behaviours. Int J Hum Resour Manag. 2013;24(18):3397-417. https:// doi.org/10.1080/09585192.2013.770779

9. Ten Cate TJ, Kusurkar RA, Williams GC. How self-determination theory can assist our understanding of the teaching and learning processes in medical education. AMEE guide No. 59. Med Teach. 2011;33(12):961-73. https://doi.org/10.3109/0142159X.2011.595435

10. Egnew TR, Lewis PR, Meyers KR, Phillips WR. The Suffering Medical Students Attribute to Their Undergraduate Medical Education. Fam Med. 2018;50(4):296-9. https://doi.org/10.22454/FamMed.2018.116755

11. Chen D, Lew R, Hershman W, Orlander J. A cross-sectional measurement of medical student empathy. J Gen Intern Med. 2007;22(10):14348. https://doi.org/10.1007/s11606-007-0298-x

12. Chen DC, Kirshenbaum DS, Yan J, Kirshenbaum E, Aseltine RH. Characterizing changes in student empathy throughout medical school. Med Teach. 2012;34(4):305-11. https://doi.org/10.3109/0142159X. 2012.644600

13. Griffith CH 3rd, Wilson JF. The loss of student idealism in the 3rd-year clinical clerkships. Eval Health Prof. 2001;24(1):61-71. https://doi.org/ 10.1177/01632780122034795

14. Hojat M, Vergare MJ, Maxwell K, Brainard G, Herrine SK, Isenberg GA, et al. The devil is in the third year: a longitudinal study of erosion of empathy in medical school. Acad Med. 2009;84(9):1182-91. https://doi. org/10.1097/ACM.0b013e3181b17e55

15. Mader EM, Roseamelia C, Morley CP. The temporal decline of idealism in two cohorts of medical students at one institution. BMC Med Educ 2014;14:58. https://doi.org/10.1186/1472-6920-14-58

16. Li H, Ding N, Zhang Y, Liu Y, Wen D. Assessing medical professionalism: A systematic review of instruments and their measurement properties. PLoS One. 2017;12(5):e0177321. doi:https://doi.org/10.1371/journal. pone. 0177321

17. Irby DM, Hamstra SJ. Parting the Clouds: Three Professionalism Frameworks in Medical Education. Acad Med. 2016;91(12):1606-11. https://doi.org/10.1097/ACM.0000000000001190

18. Gordon J. Fostering students' personal and professional development in medicine: a new framework for PPD. Med Educ. 2003;37(4):341-9.

19. Bryden P, Ginsburg S, Kurabi B, Ahmed N. Professing professionalism: are we our own worst enemy? Faculty members' experiences of teaching and evaluating professionalism in medical education at one school. Acad Med. 2010;85(6):1025-34. https://doi.org/10.1097/ACM. Ob013e3181ce64ae

20. Gracey CF, Haidet P, Branch WT, Weissmann P, Kern DE, Mitchell G, et al. Precepting humanism: strategies for fostering the human dimensions of care in ambulatory settings. Acad Med. 2005;80(1):21-8.

21. Riveros R, Kimatian S, Castro P, Dhumak V, Honar H, Mascha EJ, et al. Multisource feedback in professionalism for anesthesia residents. J Clin Anesth. 2016;34:32-40. https://doi.org/10.1016/j.jclinane.2016. 03.038

22. Goss BD, Ryan AT, Waring J, Judd T, Chiavaroli NG, O'Brien RC, et al. Beyond Selection: The Use of Situational Judgement Tests in the Teaching and Assessment of Professionalism. Acad Med. 2017;92(6):780-4. https://doi.org/10.1097/ACM.0000000000001591

23. Murray J. Development of a Medical Humanities Program at Dalhousie University Faculty of Medicine, Nova Scotia, Canada, 1992-2003. Acad Med. 2003;78(10):1020-3.

24. Krackov SK, Levin RI, Catanese V, Rey M, Aull F, Blagev D, et al. Medical humanities at New York University School of Medicine: an array of rich programs in diverse settings. Acad Med. 2003;78(10):977-82.

25. Andre J, Brody H, Fleck L, Thomason CL, Tomlinson T. Ethics, professionalism, and humanities at Michigan State University College of Human Medicine. Acad Med. 2003;78(10):968-72.

26. Franco RS, Franco CAGdS, Pestana O, Severo M, Ferreira MA. The use of portfolios to foster professionalism: attributes, outcomes, and recommendations. Assessment \& Evaluation in Higher Education. 2017;42(5):737-55. doi:https://doi.org/10.1080/02602938.2016. 1186149 
27. Kopechek J, Bardales C, Lash AT, Walker C Jr, Pfeil S, Ledford CH. Coaching the Coach: A Program for Development of Faculty Portfolio Coaches. Teach Learn Med. 2017;29(3):326-36. https://doi.org/10. $1080 / 10401334.2016 .1273781$

28. Lovell B. What do we know about coaching in medical education? A literature review. Med Educ. 2018;52(4):376-90. https://doi.org/10. $1111 /$ medu. 13482

29. Gifford KA, Fall LH. Doctor coach: a deliberate practice approach to teaching and learning clinical skills. Acad Med. 2014;89(2):272-6. https://doi.org/10.1097/ACM.0000000000000097
30. Ziring D, Danoff D, Grosseman S, Langer D, Esposito A, Jan MK, et al. How Do Medical Schools Identify and Remediate Professionalism Lapses in Medical Students? A Study of U.S. and Canadian Medical Schools. Acad Med. 2015;90(7):913-20. https://doi.org/10.1097/ACM. 0000000000000737

Publisher's Note Springer Nature remains neutral with regard to jurisdictional claims in published maps and institutional affiliations. 